\title{
Relationship between scrotal circumference and semen parameters in crossbred bulls
}

\author{
M. A. Latif1, J. U. Ahmed, M. M. U. Bhuiyan* and M. Shamsuddin \\ Department of Surgery and Obstetrics, Faculty of Veterinary Science, Bangladesh \\ Agricultural University, Mymensingh-2202, Bangladesh
}

\begin{abstract}
The relationship between the scrotal circumference and semen volume, sperm concentration and number of sperm per ejaculate of 12 crossbred bulls [ 4 Local $\times$ Friesian, 4 Local $\times$ Sahiwal] was studied. Semen of three consecutive collections at seven day intervals was evaluated. The age of bulls at first collection varied between 15 and 20 months. Soon after collection, volume, sperm concentration, number of spermatozoa per ejaculate and initial sperm motility of fresh semen were measured. Scrotal circumference was correlated with semen volume, sperm concentration and number of spermatozoa per ejaculate in both groups. A significant $(\mathrm{P}<0.04)$ positive correlation $(\mathrm{r}=0.72)$ was observed between scrotal circumference and volume of semen, and between scrotal circumference and number of sperm production per ejaculate. Significant $(P<0.05)$ variation was observed in different semen parameters between bulls within the same group, but no significant $(P>0.05)$ variation was found between the two groups. It is suggested that crossbred bulls aged 18 months or over, with scrotal circumference more than $30 \mathrm{~cm}$, yielded good quality semen. (Bangl. vet. 2009. Vol. 26, No. 2, 61-67)
\end{abstract}

\section{Introduction}

National programme for crossing local cattle with developed dairy breeds by artificial insemination (AI) has been in practice in Bangladesh since 1950 as a means for increasing milk production (Ahmed and Islam, 1987). AI has been regarded as the single most important technique for the genetic improvement of cattle (Hafez, 1993). A deficiency in a bull has a larger impact on herd productivity than fertility problems in a single female: a common saying is that the bull is half the herd. When AI is used, each ejaculate can produce 300 inseminations, representing at least 60,000 doses per bull per year (Rodriguez-Martinez, 2008). Therefore, it is extremely important in selection of breeding bulls to determine fertility.

For selection of superior sires, a progeny testing programme is crucial. Yearling bulls with larger scrotum at puberty had increased pregnancy rates in their heifer offspring (Werre and Brinks, 1986; Moser et al., 1996). Selection of young bulls at an early age is crucial for commercial semen producers. Qualitative semen traits improve with age from 12 to 16 months in Bos taurus (Cates et al., 1981) and 14 to 18

\footnotetext{
${ }^{1}$ Artificial Insemination Program, Bangladesh Rural Advancement Committee (BRAC) Head Office, 75, Mohakhali, Dhaka, Bangladesh

${ }^{*}$ Correspondence: E-mail:- mmubhuiyan@gmail.com
} 
months in Bos indicus bulls (Chenoweth et al., 1996). Selecting AI bulls at early age decreases feeding and management costs, and more rapidly improves reproduction (Hafez and Hafez, 2000).

It is suggested that crossbred bulls having bigger scrotum and earlier puberty could produce better semen (Siddiqui et al., 2008), but there is little reliable information on scrotal circumference and quality of semen. The present study was conducted to evaluate the relationship between scrotal circumference and volume of semen, sperm concentration and sperm number per ejaculate of young crossbred bulls in Bangladesh.

\section{Materials and Methods}

Animals and their management

Twelve crossbred bulls aged 15-20 months were selected from the Bangladesh Rural Advancement Committee (BRAC) Bull station, Shambhugonj, Mymensingh: 8 were Local $\times$ Friesian and 4 Local $\times$ Sahiwal. The date of birth was recorded from the registers in the Bull station. The bulls were reared in a separate clean, dry and regularly washed-floor shed at BRAC Bull station. Early every morning, the bulls were allowed to exercise in the field. A balanced diet was provided containing dry matter amounting to $2.8 \%$ of body weight. High quality roughage was a mix of one part of straw to three parts of green grass (napier, maize, sorghum, jumbo); concentrate was germinated gram 250g and BRAC Surma Special Cattle Feed ${ }^{\circledR}$ (BRAC Feed Mill, Gazipur, Bangladesh) @ $3.0 \mathrm{~kg}$. Bulls had free access to fresh water. Routine health check was done before every collection.

\section{Scrotal circumference measurements}

Bulls were restrained in a squeeze chute and the scrotal content was held in the ventral scrotum from the cranial side of the scrotum. Scrotal circumference was measured in centimetres using measuring tape (Lane Manufacturing Co., Denver, CO, USA) as described by Foote (1969).

\section{Semen collection}

The semen was collected in graduated tubes at homosexual mount using artificial vagina (AV). Three ejaculates from each bull were collected at 7-day intervals. The teaser bull was calm and appropriate size for the bull and stood on non-slippery floor during semen collection. The collection tube was sent to the laboratory immediately for semen evaluation.

\section{Semen evaluation}

The volume, sperm concentration and initial motility of spermatozoa were recorded immediately after collection. The volume of semen was recorded by reading the graduation marks on the receptacle. To evaluate sperm motility (\%), $10 \mu \mathrm{l}$ of semen was placed on a pre-warmed $\left(37^{\circ} \mathrm{C}\right)$ slide, covered with a cover slip and 
examined under phase-contrast microscope (400x). The concentration of spermatozoa was determined by using Density Spectrophotometer (SDM-5, Minitüb, Germany). Semen was diluted in cuvettes with $0.9 \%$ sodium chloride solution at the ratio of $1: 100$. The reading was recorded from the Density Spectrophotometer in million/ml.

\section{Statistical analysis}

The data were entered into Microsoft work sheet 2000. The relationship between scrotal circumference and volume, concentration and total number of spermatozoa were analysed by using pair-wise correlation test (STATA version SE-8, 2003). The data were transformed into the SPSS (Version-14, 2007) for analysis of variance (One way ANOVA) to detect variation between bulls (Anon, 1996). The variation between bulls or groups was considered statistically significant when $\mathrm{P}<0.05$.

\section{Results and Discussion}

The data on semen parameters are shown in Table 1.

Table 1. Semen parameters of two groups of crossbred bulls

\begin{tabular}{|c|c|c|c|c|c|}
\hline Breeds & Bull ID & Volume (ml) & $\begin{array}{c}\text { Sperm } \\
\text { concentration } \\
(\text { million/ml) }\end{array}$ & $\begin{array}{c}\text { Total number of } \\
\text { spermatozoa } \\
\text { (million/ejaculate) }\end{array}$ & $\begin{array}{c}\text { Sperm motility } \\
\text { of fresh semen } \\
(\%)\end{array}$ \\
\hline \multirow{9}{*}{$\begin{array}{l}\text { Local } \times \\
\text { Friesian }\end{array}$} & 69 & $5.2 \pm 2.0 \mathrm{ac}$ & $960.0 \pm 409.5^{b}$ & $5494.0 \pm 4470.6^{a}$ & $71.6 \pm 2.9 \mathrm{a}$ \\
\hline & 73 & $3.6 \pm 0.7 b$ & $1257.0 \pm 508.6 \mathrm{ab}$ & $4427.0 \pm 2611.1 \mathrm{ab}$ & $71.6 \pm 2.8 \mathrm{a}$ \\
\hline & 77 & $5.2 \pm 0.7 \mathrm{ac}$ & $1029.6 \pm 448.8 \mathrm{ab}$ & $5413.0 \pm 2840.9 a b$ & $76.6 \pm 2.8^{a}$ \\
\hline & 75 & $3.3 \pm 0.3 \mathrm{~b}$ & $531.0 \pm 96.9 c$ & $1763.0 \pm 315.5 \mathrm{bc}$ & $71.6 \pm 2.9 \mathrm{a}$ \\
\hline & 74 & $3.7 \pm 2.0 \mathrm{bc}$ & $620.0 \pm 217.6 c$ & $2088.0 \pm 626.0 \mathrm{ab}$ & $71.6 \pm 2.9 \mathrm{a}$ \\
\hline & 78 & $6.0 \pm 0.0^{a}$ & $817.7 \pm 177.7$ b & $4906.0 \pm 1066.0 \mathrm{ab}$ & $72.5 \pm 3.5 \mathrm{a}$ \\
\hline & 76 & $5.7 \pm 0.5^{\mathrm{a}}$ & $990.0 \pm 216.5^{b}$ & $5605.0 \pm 1372.0$ & $56.6 \pm 5.7 \mathrm{~b}$ \\
\hline & 84 & $3.2 \pm 0.5^{b}$ & $827.0 \pm 39.8^{b}$ & $2634.0 \pm 590.3 \mathrm{ab}$ & $36.6 \pm 23.1^{c}$ \\
\hline & Pooled & $4.5 \pm 1.1$ & $878.9 \pm 232.7$ & $4416.2 \pm 2018.1$ & $66.1 \pm 13.3$ \\
\hline \multirow{5}{*}{$\begin{array}{l}\text { Local } \times \\
\text { Sahiwal }\end{array}$} & 64 & $4.8 \pm 1.5^{a}$ & $695.0 \pm 184.5^{b}$ & $3497.0 \pm 1565.6 \mathrm{bc}$ & $76.6 \pm 7.6$ \\
\hline & 65 & $5.7 \pm 2.0 \mathrm{a}$ & $996.6 \pm 404.4^{\mathrm{ab}}$ & $5946.0 \pm 3650.7 \mathrm{ab}$ & $76.6 \pm 7.6$ \\
\hline & 66 & $2.5 \pm 1.32 \mathrm{~b}$ & $1150.3 \pm 3.5^{\mathrm{a}}$ & $2878.6 \pm 1528.3 b c$ & $80.0 \pm 0.0$ \\
\hline & 72 & $1.8 \pm 0.3 \mathrm{~b}$ & $947.6 \pm 283.7 \mathrm{ab}$ & $1791.0 \pm 745.2 \mathrm{c}$ & $73.3 \pm 2.8$ \\
\hline & Pooled & $3.7 \pm 1.8$ & $947.3 \pm 189.0$ & $3528.2 \pm 1759$ & $76.6 \pm 2.7$ \\
\hline
\end{tabular}

Values are mean $\pm \mathrm{SD}$; $\mathrm{a}, \mathrm{b}, \mathrm{c}$ Values with different superscripts in the same column differ significantly $(\mathrm{P}<0.05)$

In Local $\times$ Friesian bulls, the volume of semen varied from $3.2 \pm 0.5$ to $6.0 \pm 0.0$ $\mathrm{ml}$. The semen volume of bull $78(6.0 \mathrm{ml})$ and $76(5.7 \mathrm{ml})$ was significantly $(\mathrm{P}<0.05)$ 
higher than that of bull $73(3.7 \mathrm{ml}), 75(3.3 \mathrm{ml})$ and $84(3.2 \mathrm{ml})$. The sperm concentration varied from $531.0 \pm 96.9$ to $1257.0 \pm 508.6$ million $/ \mathrm{ml}$ and the total number of spermatozoa per ejaculate varied from $1763.0 \pm 315.5$ to $5605.0 \pm 1372.0$ million. Among eight Local $\times$ Friesian bulls, sperm concentration of bull 73 (1257.0 million/ml) and $77(1029.6$ million/ $\mathrm{ml})$ was significantly $(\mathrm{P}<0.05)$ higher than bull 75 (531.0 million/ml) and $74(620$ million/ml). Total number of spermatozoa per ejaculate of bull 76 (5605 million) and 69 (5494 million) was significantly $(\mathrm{P}<0.05)$ higher than bull 75 (1763 million). The sperm motility in Local Friesian bulls varied from $36.6 \pm 23.1$ to $76.6 \pm 2.8 \%$. Sperm motility of bull $76(56.6 \%)$ and $84(36.6 \%)$ was significantly $(\mathrm{P}<0.05)$ lower than that of other Local Friesian bulls $(71.6$ to $72.5 \%$; Table 1).

In Local $\times$ Sahiwal bulls the volume of semen varied from $1.8 \pm 0.3$ to $5.7 \pm 2.0$ $\mathrm{ml}$. The semen volume of bull $64(4.8 \mathrm{ml})$ and $65(5.7 \mathrm{ml})$ was significantly $(\mathrm{P}<0.05)$ higher than that of bull $72(1.8 \mathrm{ml})$ and $66(2.5 \mathrm{ml})$. The sperm concentration varied from $695.0 \pm 184.5$ to $1150.3 \pm 3.5$ million $/ \mathrm{ml}$ and total number of spermatozoa per ejaculate varied from $1791.0 \pm 745.2$ to $5940.0 \pm 3650.7$ million. Sperm concentration of bull 66 was significantly $(\mathrm{P}<0.05)$ higher $(1150$ million $/ \mathrm{ml})$ than bull 64 (695 million/ml). Total number of spermatozoa per ejaculate of bull 72 was significantly $(\mathrm{P}<0.05)$ lower (1791 million) than bull 65 (5946 million). The sperm motility varied from $73.3 \pm 2.8$ to $80.0 \pm 0.0 \%$. No significant variation was found in initial sperm motility between Local $\times$ Sahiwal bulls (Table 1$)$.

When the data were pooled, the semen volume $(4.5$ vs. $3.7 \mathrm{ml})$, sperm concentration (878.9 vs. 947.3 million/ml), total number of spermatozoa (4416.2 vs. 3528.2 million/ejaculate) and initial sperm motility (66.1 vs. $76.6 \%$ ) did not vary significantly $(\mathrm{P}>0.05)$ between Local Friesian and Local $\times$ Sahiwal bulls (Table 1$)$.

In the present study, more than half of the crossbred bulls can be regarded as normal based on fresh semen evaluation. However, individual bulls differed with respect to semen volume, sperm concentration, total spermatozoa per ejaculate and initial sperm motility. The differences in semen parameters among bulls may be due to variations in secretary activities of the sex glands, scrotal circumference, breed, age, body size and body weight (Graves, 1978; Leon et al., 1991; Sharma et al., 1991). Moreover, collection frequency, pre-collection stimulation, feeding regime and weather can also influence the semen parameters (Graves, 1978; Al-Hakim et al., 1986). Siddiqui et al. (2008) obtained lower volume of semen, total number of spermatozoa per ejaculate and initial sperm motility in similar aged crossbred bulls than in present study.

The scrotal circumference had a positive correlation with semen volume and total number of sperm in both groups (Figs. 1, 2 and 3), which is statistically significant $(\mathrm{P}<0.05 ; \mathrm{r}=0.72)$. 


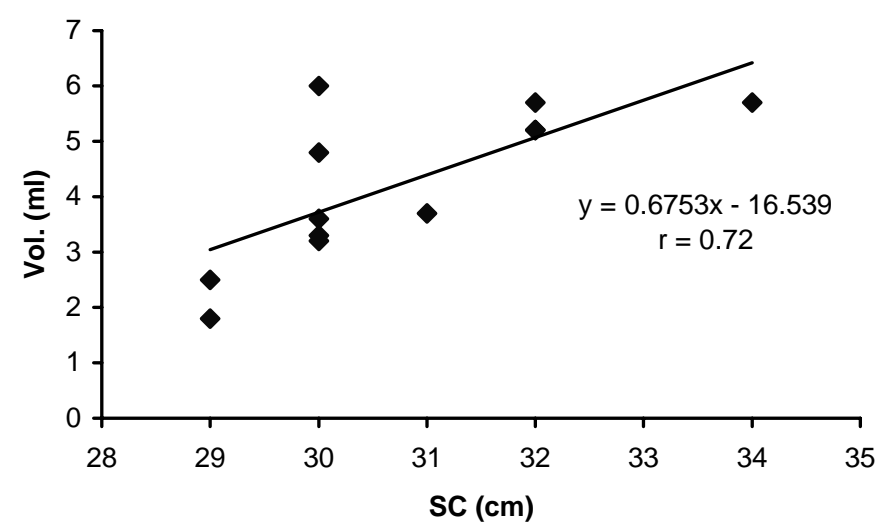

Fig. 1. Scrotal circumference and volume of semen

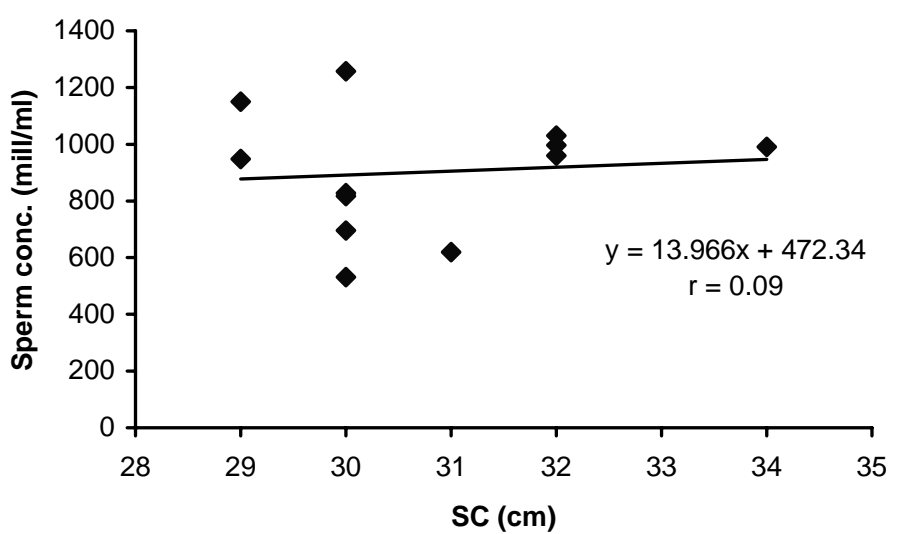

Fig. 2. Scrotal circumference and sperm concentration of semen

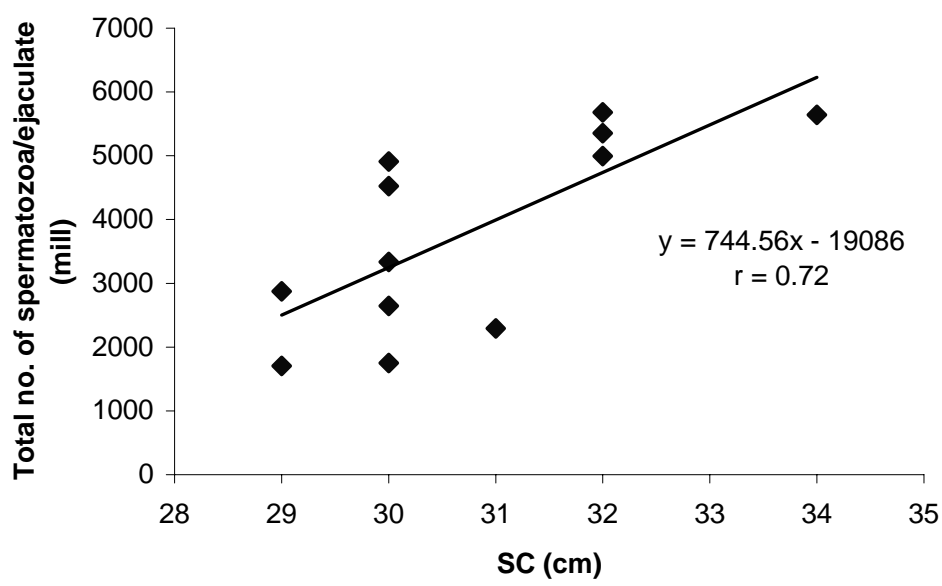

Fig. 3. Scrotal circumference and total number of spermatozoa/ejaculate

Crossbred bulls of $18.0-18.5$ months age with scrotal circumference $>30 \mathrm{~cm}$ produced good quality freezable semen (Siddiqui et al., 2008). Scrotal circumference is moderately to highly heritable and serves as a useful predictor of puberty in bulls 
(Bourdon and Brinks, 1986; Smith et al., 1989). Ball et al. (1983) reported that minimum scrotal circumference for bull irrespective of breeds should be $31 \mathrm{~cm}$ at $15-18$ months, and $32 \mathrm{~cm}$ at $18-21$ months. Young bulls with higher scrotal circumference with larger testes produced greater semen volume with more spermatozoa during the first ejaculation (Randel et al., 1994; Sundararaman et al., 2002). Bulls with smaller testes produced lower quality semen and poor calving rate when used for natural service (Randel et al., 1994). These reports in conjunction with the findings of the present study emphasize the value of measuring scrotal circumference in selecting bulls for an AI programme.

In conclusion, crossbred bulls aged 18 months or more, with scrotal circumference over $30 \mathrm{~cm}$, yield good quality semen. This study may help the AI industry in Bangladesh in selection of crossbred bulls for inclusion in an AI programme.

\section{Acknowledgements}

The authors are thankful to the Bangladesh Rural Advancement Committee (BRAC) Bull Station, Shambhugonj, Mymensingh for providing semen samples and laboratory facilities.

\section{References}

Ahmed Z, Islam TS 1987: Cattle breeding programme through artificial insemination in Bangladesh. Artificial Insemination Extension Project. Central Cattle Breeding Station, Savar, Dhaka, 2nd April, Department of Livestock Services, Dhaka, Bangladesh. pp. 1-68.

Al-Hakim MK, Ali SBA, Singh BP 1986: Studies on semen characteristics of Karadi bulls. Animal Breeding Abstracts 54155.

Anon 1996: SYSTAT ${ }^{\circledR} 60$ for Windows $^{\circledR}$ : Statistics SPSS Inc. Michigan Avenue, Chicago 12, USA, pp. 119-182.

Ball L, Ott RS, Mortimer, RG, Simons JC 1983: Manual for breeding Soundness Examination of bulls. Journal of Society for Theriogenology 12 1-65.

Bourdon RM, Brinks JS 1986: Scrotal Circumference in yearling Hereford bulls: Adjustment factors, heritabilities and genetics, environmental and phenotypic relationships with growth traits. Journal of Animal Science 62 958-967.

Cates WF, Nicholson HH, Crow GH, Janzen ED 1981: Testicular development in record of performance bulls. Proceedings of Annual Meeting, Society of Theriogenology 16-30.

Chenoweth PJ, Chase CC, Thatcher MJD, Wilcox CJ, Larsen RE 1996: Breed and other effects on reproductive traits and breeding soundness categorization in young beef bulls in Florida. Theriogenology 46 1159-1170.

Foote RH 1969: Research techniques to study reproductive physiology in the male. Techniques and Procedures in Animal Science Research, American Society of Animal Science, Champaign 111 pp. 81. 
Graves CN 1978: Semen and its components. In Salisbury GW, VanDemark NL, Lodge JR (Edn), Physiology of Reproduction and Artificial Insemination of Cattle. WH Freeman and Company, San Francisco, USA, pp. 247-285.

Hafez ESE 1993: Semen evaluation. In Reproduction in Farm Animals: Hafez ESE (Edn), Lea and Febiger, Philadelphia, pp. 405-423.

Hafez ESE, Hafez B 2000: Reproductive Cycle in Farm Animals, $7^{\text {th }}$ edn. Lippincott Williams and Wilkins, Philadelphia, USA, pp. 55-67.

Leon H, Porras AA, Galina CS 1991: Effect of the collection method on semen characteristics of Zebu and European type cattle in the tropics. Theriogenology 36 349-355.

Moser DW, Bertrand JK, Benyshek LL, McCann MA, Kiser TE 1996: Effect of selection for scrotal circumference in Limousin Bulls on reproductive and growth traits of progeny. Journal of Animal Science $\mathbf{7 4}$ 2052-2057.

Randel RD, Fields MJ, Sand RS 1994: Reproductive characteristics of Brahman and Brahman based bulls. Factors- affecting-calf crop 32 33-44.

Rodriguez-Martinez H 2008: Estimation of fertility in breeding bulls. Proceedings of $15^{\text {th }}$ International Congress on Biotechnology in Animal Reproduction, Bangladesh Agricultural University, Mymensingh, 7-8 August, Bangladesh pp. 87.

Sharma N, Mohan G, Sahni KL 1991: Characteristics and cryopreservation of semen of Holstein-Friesian bulls under tropics. Indian Journal of Animal Science 61 977-979.

Siddiqui AR, Bhattacharjee J, Das ZC, Islam MM, Islam MA, Haque MA, Parrish JJ, Shamsuddin M 2008: Crossbred bull selection for bigger scrotum and shorter age at puberty with potentials for better quality semen. Reproduction in Domestic Animals $\mathbf{4 3}$ 74-79.

Smith BA, Brinks JS, Richardson GV 1989: Relationship of sire scrotal circumference to offspring reproduction and growth. Journal of Animal Science 67 2881-2885.

Sundararaman MN, Thangaraju P, Edwin MJ 2002: Age related changes in testes size of Jersey bulls and its effects on semen production traits. Indian Journal of Animal Sciences 72 567-568.

Werre JF, Brinks JS 1986: Relationship of age at puberty with growth and subsequent productivity in beef heifers. Proceedings of Western Section American Society for Animal Science 37300. 